adsorption of mothanol was very considerably reduced on heated 'Sterchamol' compared with normal 'Sterchamol'. Another widely used support, 'Chromosorb $W$ ', was found to be significantly better than 'Sterchamol', but not so good as heated 'Sterchamol'. The practical improvement resulting from this treatment was demonstrated in the symmetrical peaks obtained for $\mathrm{C}_{3}-\mathrm{C}_{6}$ ketones, alkylacetates, and up to $\mathrm{C}_{6}$ alcohols on a $1 \mathrm{~m} \times 4 \mathrm{~mm}$ diameter column of 1 per cent squalane on heated 'Sterchamol' at $80^{\circ} \mathrm{C}$. In the discussion which followed, Dr. Huber said that he used a small mesh size (about 100 B.S.S.), that heating in air, nitrogen or vacuum produced the same effect, and that he only sieved out fine particles before use, and did not regrind after heating in order not to expose fresh surfaces which might have high adsorptive capacity. It is possible to absorb up to 10 per cent of a liquid phase on the heated 'Sterchamol' if required.

The final paper of the meeting was on "The Effect of Stationary Phase Viscosity on Column Efficiency", by Mr. S. J. Hawkes. References in the literature to this effect are few and contradictory and therefore Mr. Hawkes has attempted to correlate data on a variety of liquid phases over a range of temperature, and to suggest the minimum temperature at which well-known liquid phases can be used for a given resolution. The relationship between the diffusivity, $D$, in the liquid phase and the viscosity, $\eta$, was discussed in terms of the Amold equation, which proposes that $D \propto \eta^{-2}$, and the Herzog equation, which proposes that $D \propto \eta^{-1}$. The results of Littlewood for $n$-octane and 2-methyl-pentane on tricresylphosphate supported on glass beads were taken to show that a twelvefold change in viscosity (with temperature) only gave a 1.5-fold change in the diffusivity term if this were assumed to be proportional to $\eta^{-1}$, compared with a 6 -fold change if assumed proportional to $\eta^{-2}$. Similarly, benzene on poly. propylenesebacate supported on treated 'Celite' over the range $25^{\circ}-145^{\circ} \mathrm{C}$ gave an almost constant $\eta^{-1}$ term.
Mr. Hawkes therefore considered that the Herzog equation best fitted the data, but that an additional empirical factor was necessary to make the diffusivity factor constant for all solutes on a given liquid phase. The experimental values for the height equivalent of a theoretical plate agreed with the values calculated from the modified Herzog treatment within a factor of 3 for various liquid phases, temperatures, and solutes. One conclusion was that there should be little restriction on the minimum operating temperature of packed columns except porhaps for solutes with low partition coefficients or for complex liquid phases, for example, substituted adipates and sebacates. However, with capillary columns the effect of viscosity can be important if the thickness of the liquid film is $10^{-4} \mathrm{~cm}$, but with a film thickness of $10^{-5}$ am there should not be serious difficulties.

This paper stimulated considerable discussion, and Dr. R. P. W. Scott stressed the practical importance of the effect of temperature on the resolution of a pair of solutes in a column rather than its effect on the maximum efficiency. It was pointed out by Dr. A. J.P. Martin that good separations can be achieved with a stationary phase of rubber, which has an extremely high viscosity. Dr. T. Smith commented that silicone gums with a high viscosity also give good separations in practice, and that he considered that the relative polarities of solutes and solvents was of importance in determining the effect of viscosity. $\mathrm{He}$ expected the behaviour of non-polar solutes to be little affected by the viscosity of a non-polar solvent but the interaction of polar and non-polar molecules to be considerably affected by viscosity.

In conclusion, it would soem that this symposium was successful because it offered something for everyone rather than specializing on one narrow topic, and that the Group should be encouraged to give similar balanced programmes at future meetings.

C. J. HARDY

\title{
MICROBIOLOGY AND WORLD FOOD SUPPLIES
}

$\mathrm{A}^{\mathrm{T}}$ T the eighth International Congress for Microbiology, held in Montreal during August 1962, the following resolution was adopted:

(1) The International Association of Microbiological Societies, in sympathy with the Food and Agriculture Organization's Freedom from Hunger Campaign, has noted with concern the widening gap between the global rates of increase of population and of food supply, at a time when there already exists famine or near-famine in many parts of the world. The Association has accordingly considered how microbiology might help towards a future need, clearly indicated, to increase world food production by all conceivable means.

(2) One attack on this problem is to improve the fertility of soils, in which connexion the following would be helpful: (a) A study of thermophilic and mesophilic micro-organisms capable of more rapidly transforming such non-food wastes as sawdust, straw, weeds, leaves, sludge, etc., into suitable organic matter of manurial value. (b) Research on the effect of herbicides, fungicides and other chemicals on micro-organisms, in order to attempt to control soil populations. (c) Further studies on the effectiveness and wider distribution of Azotobacter, Rhizobium and other micro-organisms capable of fixing atmospheric nitrogen.

(3) There is also the possibility of producing, from appropriate micro-organisms, agriculturally useful substances, such as plant growth factors and inhibitors.

(4) Another obvious line of attack is to prevent spoilage of food by micro-organisms. There are well-proved ways of doing this, such as drying, salting, refrigeration or canning; and there are new methods of promise, such as the use of antibiotics or irradiation; all these are worth investigating. On an international view, however, it is much more urgent to apply what is already known to countries where such methods are under-developed, rather than to devote effort to minor improvements in existing procedures. Moreover, it must be recognized that even if food spoilage by microbes were entirely pre. vented, the increase in total available food would bo small (of the order only of a few per cent, though the benefits might be greater in some places).

(5) To change the situation radically, sources of food additional to orthodox agricultural production must be sought for man and his domestic animals. It should be realized that micro-organisms should be capable of supplying some of these; for micro-organisms are able to produce edible protein, fat or carbohydrate, and vitamins, from materials entirely inaccessible to human or mammalian digestion, yet do not require agriculturally useful land.

(6) As examples of micro-organisms worthy of examination, the following are suggested: $(a)$ Organisms utilizing existing agricultural or industrial by-products (food yeast is the best known example). (b) Fungi and bacteria decomposing cellulose or hemi-cellulose (for example, woody plant tissue). (c) Fungi attacking wood, especially lignin (some of these are known to be edible). (d) Organisms which decompose the larger sea weeds. (e) Organisms capable of multiplying in various effluents (for example, aquatic fungi). $(f)$ Bacteria capable of oxidizing methane or other hydrocarbons. $(g)$ Photosynthetic algae or bacteria (Chlorella is the best investigated example). Particular interest would attach to organisms capable 
at the same time of converting atmospheric nitrogen into protein, which probably exist in soveral of the foregoing groups.

(7) Preliminary essays in this direction, the production of food yeast and of Chlorella have been discouraged by two factors: first, because insufficient attention has been directed to the preparation of sufficiently attractive materials from the crude micro-organism; socondly, and more important, by the demonstration that such products do not yet compete economically with orthodox foods. But, with increasing demands on orthodox food supplies, this situation may soon change.

(8) The world shortage seems likely to become acute in the next ten or twenty years, which is not a long period for developmental research of the nature likely to be requirod, especially as many of the relevant mieroorganisms have been little studied hitherto. 'To permit, application of such research in time, it is recommended that Governments encourage it now, even though it bo uneconomic at prosent.

\section{THE CARNEGIE UNITED KINGDOM TRUST}

T

HE forty-ninth annual report of the Carnegie United Kingdom Trust*, covering the year 1962, in which grant payments fell to $£ 74,870$ from $£ 152,533$ in 1961 , deals largely with the working out of settled policies in the second year of a quinquennium. A start was made with the distribution of a quinquennial allocation of $£ 100,000$ for the social requirements of new communities in offers of up to $£ 10,000$ to the Borough Council of Thetford, one-third of the possible cost of developing a central site for this purpose, and $£ 1,000$ to the Basildon Youth Association. A launching grant of $£ 3,000$ was made towards the establishment of the headquarters of a National Bureau for Co-operation in Child. Care. The quinquennial allocation of $£ 100,000$ for the youth service has now been committed to the extent of one-quarter in the form of improvement grants for 160 youth clubs, but there is still a dearth of new ideas which are pioneer in the national sense and not supported from other sources.

In the Arts, the Trust is maintaining its annual subvention of $£ 1,000$ to the Museums Association until the end of March 1964, and a special grant of $£ 1,000$ was awarded for up-to-date office equipmont and appointmonts in the Association's new headquarters. Sixteen expert reports were commissioned at the request of muscums throughout Britain, and arising out of these or earlier reports nine grants, totalling $\$ 5,350$, were recommended for immediate improvements in existing displays, and expenditure of $£ 6,000$ on museums reorganization included expenditure on schemes of improvement at twelve museums completed during the year and payments to account for expenditure on six similar projects.

Under education, besides the grants for youth service already noted, a small grant of $£ 270$ was made to the * The Carnegio United Kingdom Trust. 49th Annual Report, 1962
Pp. viii + 66. (Dunfermline, Fife: Carnegie United Kingdom Trust: 1963).
Young Men's Christian Association at Norwich to provido equipment for use in day camps for young people with which the Association is experimenting. The Trust is also contributing up to $£ 20,000$ towards the cost of a centre in the Brecon Beacons National Park, on a site adjacent to Mynydd Illtyd Common, as a mountain rendezvous and shelter on the understanding that the remaining capital cost and maintenance will bo provided by Government grant or local authorities. Bursaries were paid to 44 people attending courses at field-study centres in England and Wales and 24 to others attending courses in Scotland, and over the six years of this policy more than 500 people have received bursaries. Grants totalling $£ 915$ were made to archæological societies towards the cost of 14 prectical projects in which amateurs could be trained under skilled direction, and it is estimated that about 300 people participated, but only two applications were received for grants under a similar scheme for the benefit of natural history societies associated with the Council for Nature. A furthor grant of $£ 3,000$ went to the Couneil for Nature for the expenses of the Conservation Corps, which should become independent of the Trust's subvention by the end of 1963. Grant aid continued to the British Astronomical Association for promoting astronomy as a worth-while amateur activity, but only four events were carried through - three being wellattended open meetings, for which grants will not in future be available. Assistance is also being given to the Royal Meteorological Society to meet a growing interest in moteorology as an educational and cultural pursuit for amateurs and, for the four years 1962-65, £2,000 has been allocated at the rate of $\$ 500$ an year. In 1962 this was spont mainly on eight courses, five at field studies centres, one at Falmouth Sailing Centre on weather and sailing, and two on meteorology and gliding at Lasham Aerodrome, near Alton, and at Portmoak, Kinross-shire.

\section{TEXAS INSTRUMENTS INC.}

T HE 1962 annual report of Texas Instruments Inc. Dallas, Texas*, states that the Company continues to be the world's leading producer of semi-conduetors, although they constituted less than half tho Company's sales volume. Texas Instruments is one of few manufacturers the semi-conductor operations of which remained. profitable in the face of continued sovere price competition. It attributes this succoss to the emphasis placed on the mechanization of manufacturing processes. More than a hundred difforent types of transistors were introduced during 1962.

The report highlights the increasing demand for the Company's 'Solid Circuit' semi-conductor networks. 'These integrated circuit deviees are to bo used in the improved.

* Texas Instruments Inc. 1962 Annual Report. Pp. 8. (Dallas: Texas Instruments Inc., 1963.) version of the Minuteman intercontinental ballistic missilo, and initial production-quantity ordors totalling moro than a rnillion dollars havo been recoived. In addition, contracts for networks to be used in an improved airborne radar computer indicator for the naval $W 2 F-1$ oarlywarning aircraft and for use in an important airborne electronic countermeasures system have been obtainod. The production of new metallurgical, eloctrical and thermostatic devices reached a high lovel, as also nuclear core fabrication for which new contracts in excess of twenty-one million dollars were received during the year.

Dealing with goophysical activities, tho roport mentions that a numbor of significant new seismic signal enhancement methods which reached the production stage aided considerably the petroleum exploration services of the Company. The throe marine exploration vessels 